\title{
Development and Validation of Critical Thinking Skills Instruments of Physics Subjects
}

\author{
Khaeruddin ${ }^{1}$, Bunga Dara Amin ${ }^{2}$ \\ $\left\{\right.$ khaeruddin@unm.ac.id $\left.{ }^{1}\right\}$ \\ Lecturer in Physics Education Study Program, Universitas Negeri Makassar, Indonesia \\ Jl. Daeng Tata Raya Kampus Parangtambung UNM Makassar 90224,
}

\begin{abstract}
The Indonesian curriculum explicitly states that critical thinking skills as Higher Order Thinking Skills (HOTS) and future competencies must be taught to students to answer the challenges of globalization and be able to adapt to changes and respond to the demands of the 21 st century. Therefore, this paper explains the development and validation of instruments of critical thinking skills to assess the ability to interpret, the ability to analyze and the ability to infer students. Specifically, critical thinking skills tests are designed based on the basic competencies of high school physics subjects in the form of essays that are equipped with an assessment rubric. Evidence of content validity, construct validity, and reliability are presented as the reliability of the critical thinking test instrument.
\end{abstract}

Keywords: Critical Thinking Skills, Instrument Development, Instrument Validation

\section{Introduction}

The results of the international study Program for International Student Assessment (PISA) show the achievement of reading literacy, mathematical literacy, and scientific literacy achieved by Indonesian students is very low. This means that Indonesian students are very low in (1) understanding complex information; (2) theory, analysis and problem solving; (3) use of tools, procedures and problem solving; and (4) investigating. In addition, the results of Khaeruddin's research [1] in several High Schools (SMA) in Makassar (SMAN 2 Makassar, SMAN 9 Makassar, SMAN 10 Makassar, SMAN 14 Makassar and SMAN 15 Makassar) show that: (i) the formulation of the assessment or questions is only product-oriented cognitive, even none of the questions that lead to cognitive processes, namely Higher Order Thinking Skills (HOTS), (ii) low critical thinking skills of students in high school, namely the average value of students interpreting, analyzing, and inference respectively $1.53,1.15$, and 1.52 of the maximum value that students might obtain is 10. Even the results of Khaeruddin's research [1], critical thinking skills of students in high school are still low, namely the average value of students doing interpretation, analysis, and inference respectively $32.29,36.32$, and 41.67 of the maximum value that may be obtained by students is 100 . Whereas the demands of the Indonesian Curriculum expressly express critical thinking skills as future competencies that must be taught to students to answer the challenges of globalization and be able to adapt to changes and respond to the demands of the 21 st century. Based on the above facts, this research aims to develop and produce a reliable critical thinking assessment to optimize the HOTS ability of students through Physics in high school. 


\section{Method}

This research is developing critical thinking assessment through Physics in order to optimize the HOTS of students in high schools. Therefore, the research design is the Educational Design Research (EDR). The Indonesian curriculum explicitly states that critical thinking skills as future competencies must be taught to students to answer the challenges of globalization and be able to adapt to changes and respond to the demands of the 21 st century. To achieve the objectives of this research, the activities carried out are adjusted to the 2019 research roadmap, namely: (i) reviewing several journals, learning theories, Model of Teaching (MoT) relating to "critical thinking". Based on some opinions, almost unanimous experts $(\mathrm{N}>95 \%)$ include analysis and inference as the core of critical thinking skills and there is a strong expert consensus $(\mathrm{N}>87 \%)$ which states that interpretation is also the core of critical thinking skills [2] such as Burden \& Byrd [3]; Beyer [4]; Rudinow \& Barry [5], the researchers state that critical thinking skills are thinking skills that involve high-level cognitive processes, namely interpretation, analysis, and inference through scientific procedures in order to solve problems. Therefore, the authors make as an indicator of critical thinking skills are interpretation, analysis, and inference; (ii) Basic Competency (BC) analysis of Physics subjects in the 2013 Curriculum. The basic competencies analyzed are the materials of Straight Motion with Constant Speed and Acceleration [6].

Table 1. Basic Competence of Senior High School Class X.

"Straight Motion with Constant Speed and Acceleration"

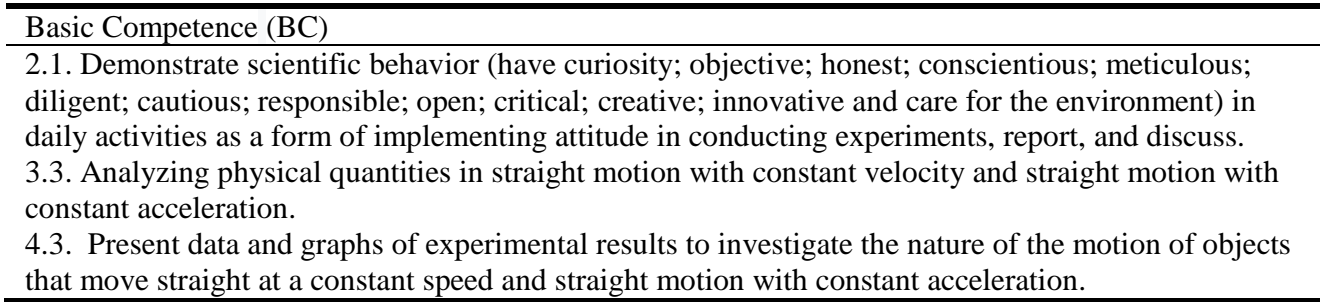

Table 1 above found key words on basic competencies such as scientific behavior (including curiosity, objective, honest, thorough, careful, diligent, cautious, responsible, open, critical, creative, innovative and caring for the environment), conduct experiments and discuss, analyze, present data and graphs. These keywords correspond to indicators of critical thinking skills. Even the suitability is shown from the definition which states that critical thinking skills are thinking skills that involve high-level cognitive processes, namely interpretation, analysis, and inference through scientific procedures in order to solve problems; (ii) formulating indicators based on $\mathrm{BC}$ as a reference for assessment; Basic Competence 2.1, is translated into several indicators of achievement of BC 2.1 as an affective indicator. The results of the formulation of affective indicators, namely 2.1.1. show perseverance in conducting experiments; 2.1.2. Showing responsibility in conducting experiments. Basic Competence 3.3, is translated into several indicators of achievement of BC 3.3 as an indicator of knowledge. The results of the formulation of indicators of knowledge/cognitive products oriented to Critical Thinking Skills (CTS), namely 3.3.1. interpret data based on the relationship between the slope magnitude and the travel time; 3.3.2 Analyze truck trip data; 3.3.3 Referencing based on the 
graph of Juanita and Heather's trip to the beach. Basic Competence 4.3, translated into several indicators of achievement BC 4.3, translated into several indicators of achievement BC 4.3 as an indicator of knowledge/Cognitive Performance (Science Process Skills), which is 4.3.1. Formulate problems, formulate hypotheses, identify variables, formulate operational definitions of variables, make tables, make graphs, analyze, interpret, draw conclusions from experimental results about the effect of slope on travel time; (iii) design the assessment based on critical thinking indicators by adjusting BC achievement indicators. The CTS assessment was designed in the form of essays totaling 12 question items. The details of the number of question items are as in Table 2 below.

Table 2. The number of questions for each indicator of CTS.

\begin{tabular}{lll}
\hline Critical Thinking Skills & Item Number & Number of items \\
\hline Interpretation & $1,2,3,4$ & 4 \\
Analysis & $5,6,7,8$ & 4 \\
Inference & $9,10,11,12$ & 4 \\
\hline
\end{tabular}

The design of critical thinking skills assessment refers to the CTS description as shown in Table 3.

Table 3. The domain of scientific literacy competence on instruments.

\begin{tabular}{ll}
\hline Indicators & Descriptions \\
\hline Interpretation & Rational explanation of the data analyzed is based \\
& on patterns or tendencies that are described from \\
& graphs or tables [7] \\
Analysis & a. Data is organized in the form of tables, graphs \\
& and/or diagrams \\
& b. Explain data patterns that show relationships \\
& between variables. \\
& {$[8,7]$} \\
Inference & Explain an idea or express initial conclusions \\
& based on observations or statements [2]. \\
\hline
\end{tabular}

Because the critical thinking skills test is designed in the form of an essay, then to correct the answers to the questions formulated assessment guidelines (rubrics) to be objective.

\section{Results}

The instrument tests validation of CTS through face validation conducted by two experts using the expert judgment method. Face validation refers to the material, construction and language. In detail the results of the validation as shown in Table 4. 
Table 4. Validation results of CTS tests.

\begin{tabular}{|c|c|c|c|c|c|}
\hline \multirow{2}{*}{ No. } & \multirow[t]{2}{*}{ Rated aspects } & \multicolumn{2}{|c|}{ Validator (V) } & \multirow{2}{*}{$\begin{array}{l}\text { Diffe- } \\
\text { rence }\end{array}$} & \multirow{2}{*}{$\begin{array}{l}\text { Reliabi- } \\
\text { lity }(\%)\end{array}$} \\
\hline & & $\mathrm{V} 1$ & V2 & & \\
\hline I & Theory & & & & \\
\hline 1 & $\begin{array}{l}\text { The items in accordance with the } \\
\text { indicators }\end{array}$ & 4 & 4 & 0 & 100.00 \\
\hline 2 & $\begin{array}{l}\text { the contents of the material in } \\
\text { accordance with the measurement } \\
\text { objectives }\end{array}$ & 4 & 4 & 0 & 100.00 \\
\hline 3 & $\begin{array}{l}\text { the contents of the material in question } \\
\text { in accordance with the level of } \\
\text { education }\end{array}$ & 4 & 4 & 0 & 100.00 \\
\hline II & Construction & & & & \\
\hline 4 & The items are clearly formulated & 4 & 4 & 0 & 100.00 \\
\hline 5 & $\begin{array}{l}\text { The formulation of the problem is } \\
\text { formulated firmly }\end{array}$ & 4 & 4 & 0 & 100.00 \\
\hline 6 & $\begin{array}{l}\text { The discourse, picture or graphic really } \\
\text { works and has something to do with } \\
\text { the problem in question }\end{array}$ & 3 & 4 & 1 & 85.71 \\
\hline 7 & $\begin{array}{l}\text { Between items do not depend on each } \\
\text { other }\end{array}$ & 4 & 4 & 0 & 100.00 \\
\hline III & Language & & & & \\
\hline 8 & Communicative sentence formulation & 3 & 3 & 0 & 100.00 \\
\hline 9 & $\begin{array}{l}\text { Sentences use good and correct } \\
\text { language }\end{array}$ & 4 & 4 & 0 & 100.00 \\
\hline 10 & $\begin{array}{l}\text { The sentence formulation does not lead } \\
\text { to a double interpretation }\end{array}$ & 3 & 3 & 0 & 100.00 \\
\hline 11 & $\begin{array}{l}\text { Use common language and/or verbs } \\
\text { (not local language) }\end{array}$ & 4 & 4 & 0 & 100.00 \\
\hline & Total & 41 & 42 & 1 & 98.80 \\
\hline & Average & 3.73 & 3.82 & & \\
\hline
\end{tabular}

Table 4 shows that the items that have been developed have good quality, this is evidenced by the results of the validation of the validator giving a rating of 4.00 (content validation) and 3.75 (construct validation) for the material of straight motion with the level of reliability of each amounted to $100.00 \%$ and $96.87 \%$. This is supported by communicative sentence formulation, using good and correct language, sentence formulation does not lead to multiple interpretations and uses common language and verbs (not local language). In general, each validator gave an assessment of 3.73 and 3.82 , including the category of very valid with a reliability level of 
$98.80 \%$. This shows that the items in accordance with the indicators, measurement objectives, and education levels can be relied upon consistently measuring HOTS, namely critical thinking skills. The validation results above support the Curriculum of 2013 which requires the use of assessment oriented to HOTS. In the context of education based on standards (standard-based education), curriculum based on competency (competency-based curriculum), and the mastery learning approach to the assessment of the process and learning outcomes are parameters of the level of achievement of minimum competency. Thus, various approaches, strategies, methods, techniques, and learning models need to be developed to facilitate students to easily learn and achieve optimal learning success. Therefore, in learning science, tests should apply scientific literacy which is an element of life skills that must be the result of education. In addition, scientific literacy is one of the domains of assessment in the PISA. Science literacy is the ability needed (need) to be taught to students for life in the future both as individuals and as members of society.

\section{Conclusion}

Item Critical Thinking Skills that have been developed through expert judgment have good quality. However, to test its reliability, an empirical test will be conducted.

\section{References}

[1] Khaeruddin, K.: Fostering Critical Thinking Skills through Optimizing Science Process Skills in Physics Learning. IOSR Journal of Research \& Method in Education (IOSRJRME), 6(6), pp. 103-108 (2016)

[2] Nur, Nasution, \& Suryanti, J.: Berpikir kritis. Laporan Penelitian Unggulan Perguruan Tinggi). Surabaya: Unesa (2013)

[3] Burden, P. R., \& Byrd, D. M.: Methods for effective teaching: Meeting the needs of all students. Pearson (2007)

[4] Beyer, B. K.: What research tells us about teaching thinking skills. The Social Studies, 99 (5), pp. 223-232 (2008)

[5] Rudinow, J., \& Barry, V. E.: Invitation to critical thinking. Cengage Learning (2008)

[6] Kemdikbud.: Standar Kompetensi dan Kompetensi Dasar. Jakarta: Kemendikbud (2016)

[7] Kheng, Y. T.: Science Process Skills Form 4. Selangor: Pearson Longman (2008)

[8] Hackett, J. K., Richard H. M., Vasquez, J., Teferi., M., \& Zike, D.: Science, Grade 4: A closer look: Macmillan/McGraw-Hill (2011) 